\title{
Pleiotropic Immune Functions of Chemokine Receptor 6 in Health and Disease
}

\author{
Ranmali Ranasinghe and Rajaraman Eri * (iD \\ School of Health Sciences, College of Health and Medicine, University of Tasmania, Launceston, Tasmania 7250, \\ Australia; ranmaliranasinghe301@gmail.com \\ * Correspondence: rajaraman.eri@utas.edu.au; Tel.: +61-3-6324-5467
}

Received: 6 June 2018; Accepted: 27 June 2018; Published: 2 July 2018

\begin{abstract}
C-C chemoattractant cytokine (chemokine) receptor 6 (CCR6) and its exclusive binding molecule CCL20 is an extremely important chemokine receptor-ligand pair which controls cell migration and immune induction during inflammatory disease. Not many scientific studies have been undertaken to study its immune mechanisms in detail, but its unique contribution to steady state cell chemotaxis in upholding immune tolerance and regulating immune homeostasis during inflammation is evident in multiple systems in the human body, including skin, liver, lung, kidney, brain, eye, joints, gonads and the gut. The role of CCR6 is constitutively expressed as a series of much debilitating severe inflammatory and autoimmune diseases, Human Immunodeficiency Virus (HIV) and cancer metastasis. $\mathrm{CD}^{+} \mathrm{T}$ cells, the central organizers of adaptive immunity, are stringently mobilized by the CCR6/CCL20 axis also induced by cytokines and a host of other factors in a carefully executed immune modulation scenario, to bring about a delicate balance between inflammation inducing $\mathrm{T}_{\mathrm{H}} 17$ cells and regulatory $\mathrm{T}_{\text {reg }}$ cells. Although the exact immune regulatory role is not elucidated as yet, the CCR6/CCL20 axis is implicated as a front runner which determines the polarization of $\mathrm{T}_{\mathrm{H}} 17$ and regulatory $\mathrm{T}_{\text {reg }}$ cells, upon which depends the resolution or progression of many debilitating disorders. This review therefore aims at emphasizing the pleiotropic significance of the chemokines CCR6 and CCL20 in immunologic function in multiple organ systems, thereby hoping to accentuate its value in future therapeutic modalities.
\end{abstract}

Keywords: CCR6; CCL20; $\mathrm{T}_{\mathrm{H}} 17 ; \mathrm{T}_{\text {reg; }}$ inflammation; multiple organs; health and disease

\section{Introduction}

\section{Chemokines}

Chemokines represent an exclusive cell directing system in the body, consisting of signaling proteins vital to the immune system. The primary role of chemokines in infections is to attract immune cells bearing their cognate receptors to sites of inflammation. The best example is corroborated by the role of chemokines in mucosal immunity, where epithelial cells of the mucosa activated by an inflammatory stimulus releases the chemokine ligands, constitutively inducing chemotaxis of the leukocytes bearing their corresponding receptors towards them [1]. This is necessarily how chemokines mediate immune modulation and maintain cell migration during immune homeostasis or inflammation. Chemokines have also been described by other names, such as a specific 'cell positioning' system [2] or a potential 'cell navigating' system [1] which brings about immune modulation in multiple organ systems of the human body.

The chemokine repertoire described so far includes 50 different chemokines and 20 different receptors. Chemokine receptors are externally displayed on the surface of a range of cells [2] such as $\mathrm{T}$ 
and B lymphocytes, macrophages, dendritic cells, peripheral blood mononuclear cells, innate lymphoid cells, neuron, epithelial and endothelial cells [3].

Chemokines, abbreviated from 'chemoattractant cytokines', mediate their biological effects across G-protein coupled receptors [1]. These surface-bound receptors are specifically borne by a wide range of immune and non-immune cells. Biochemically, chemokine receptors function as guanine nucleotide exchange factors, mainly limited to the pertussis-toxin sensitive G1 class of $G$ proteins. Their immunological effects consist of coordinating leucocyte development, differentiation, distribution, chemotactic migration and their effector capabilities [4]. The biological impact of chemokines produces multiple outcomes: (i) embryonic development; (ii) angiogenesis; (iii) T-helper subset development; (iv) leukocyte homeostasis; (v) wound healing; (vi) lymph organogenesis; (vii) inflammatory disorders; (viii) tumor proliferation and metastasis; and (ix) B cell maturation and antigen-induced B cell differentiation [1,4-8].

Chemokines consist of small proteins having a molecular weight of 8 to 14 kilo Dalton [9]. The structure reveals three beta pleated sheets with an alpha helix at the carbon terminal and disulfide bonds connecting cysteine subunits. Chemokines are said to be composed of secreted, structurally related proteins having $67-127$ amino acids. The functional form is highlighted as a monomer, although they could exist as either a monomer, dimer or tetramer [1]. Chemokines are named based on their receptors and each sub class, CC, CXC, CX3C or XC is identified by the number and spacing of preserved cysteines. $\mathrm{R}$ denotes receptor and it is followed by a number which lists out the chronological order of discovery [9]. Thus "CC chemokines have CCR chemokine receptors" to bind with. Some chemokines bind specifically to one receptor such as the cognate receptor, CCR6 and its exclusive ligand, CCL20. Chemokines can ligate with more than one receptor or several chemokine receptors can attach to more than one chemokine, among which the CCR6 and its ligand CCL20 forms an exclusive monogamous pair [1]. Chemokines are known to actively recruit immature or effector cells to affected sites during maintenance of immune tolerance or promoting inflammation, but interestingly inhibition of chemokines have shown to develop anti-inflammatory properties, encouraging the exploration of novel therapeutic breakthroughs in medical treatment [10].

Chemokine-aided $\mathrm{T}$ cell chemotaxis is directly linked to a number of immune-activated diseases. Leukocyte migration from blood to tissue is a multi-step process. It involves selectin-mediated rolling on endothelium and chemoattractant-mediated integrin activation, followed by leukocyte extravasation and chemotaxis up a chemoattractant gradient [4]. Upon synthesis within the cell, chemokines are secreted and get tethered to glycosaminoglycans, a group of sulfated polysaccharides present in the extracellular matrix or surface which constructs a steady chemokine gradient that ensures binding with its receptor [1].

\section{Chemokine Receptor CCR6 and Its Ligand CCL20}

CCR6 in Homo sapiens is identified by many synonymous codes: DCR2, DRY6, BN-1, CCR-6, CMKBR6, GPRCY4, STRL22, CD196, CKRL3, GPR29, CKR-L3, CC-CKR-6 or C-C CKR-6 [11]. CCL20 was identified as the sole known ligand to bind with CCR6 using CCL20 induced mobilization of calcium in K562 cells devoid of other receptors (CCR1-5) except CCR6 [1]. Five other chemokines (CCL2-5 and 17) did not bind to CCR6, although there is documented research stating CCL18 as a possible binding partner [12]. When CCL20 binds to CCR6, the receptor becomes internalized with its expression reduced on the cell surface [1]. Beta-defensins, a group of anti-bacterial peptides, have been shown to elicit chemotaxis through CCR6 although its activity on CCR6 still remains experimental [13].

CCL20, discovered using bioinformatics techniques is known by several names such as, macrophage inflammatory protein (MIP3 $\alpha$ ), Exodus- 1 and liver and activation regulated chemokine (LARC). Th17 cells are known to express CCL20 but it is not expressed by the regulatory T cells or other T helper subsets [1]. CCL20 expression is markedly up regulated in the intestinal epithelial cells only as a response to intrusive or non-intrusive bacteria possessing flagella, and is labelled as 
an inflammation-inducing chemokine [14]. Cells linked to inflammation such as endothelial cells, neutrophils, Th17 cells, B cells, natural killer (NK) cells, dendritic cells, macrophages and Langerhans cells, reportedly express CCL20 [15].

CCR6 is naturally expressed in multiple tissues: maximally in the appendix, spleen, lymph nodes and pancreas and minimally in the thymus, colon, small intestine, fetal liver and testis [11]. CCR6 is upregulated by numerous leukocyte cohorts, such as B-cells, T-cells (specifically pro-inflammatory $\mathrm{T}_{\mathrm{H}} 17$ cells and immune regulatory $\mathrm{T}_{\text {reg }}$ cells), immature dendritic cells, NKT cells, innate lymphoid cell 3 and neutrophils [16].

The dominant role of CCR6 in inflammatory disease is underpinned by its influence on driving the $\mathrm{T}$ helper subset differentiation and maintaining leukocyte homeostasis. Naïve $\mathrm{T}$ helper cells resident in lymph nodes, upon antigen sampling will differentiate into its effector sub populations, $\mathrm{T}_{\mathrm{H}} 17$ and regulatory $\mathrm{T}_{\text {reg }}$ cells, $\mathrm{T}_{\mathrm{H}} 1$ and $\mathrm{T}_{\mathrm{H}} 2$, mediated by the prevailing cytokine environment and a host of other factors. However a critical factor which determines the development of $\mathrm{T}_{\mathrm{H}} 17$ and $\mathrm{T}_{\text {reg }}$ subsets evidently becomes the upregulation of CCR 6 as both these cell sub types are known to be CCR6 ${ }^{+} \mathrm{CD} 4^{+}$ $\mathrm{T}$ cells. Thus proliferation, migration and promoting pro-or anti -inflammatory effects of these helper sets might be primarily CCR6 dependent processes [17].

$\mathrm{CD}^{+} \mathrm{T}$ helper cells are the most important key players in organizing adaptive immunity. Naïve $\mathrm{CD} 4{ }^{+} \mathrm{CD} 45 \mathrm{RB}^{\text {high }} \mathrm{T}$ cell populations, when activated by antigen presenting cells, differentiate into the mainstream $\mathrm{T}_{\mathrm{H}} 1$ and $\mathrm{T}_{\mathrm{H}} 2$ classical lineages. They regulate cellular immunity through their respective signature cytokine profiles, namely, IFN- $\gamma$, TNF- $\alpha$ and IL- $1 \beta$ in $\mathrm{T}_{\mathrm{H}} 1$ and IL- 4 , IL- 5 and Il-13 in $\mathrm{T}_{\mathrm{H}} 2$. $\mathrm{T}_{\mathrm{H}} 1$ is pro-inflammatory by nature while $\mathrm{T}_{\mathrm{H}} 2$ mediates humoral and allergic responses [18]. $\mathrm{T}_{\mathrm{H}} 1$ and $\mathrm{T}_{\mathrm{H}} 2$ differ in immune function as well as migratory capability by expressing distinct chemokine e receptors which modulate selective recruitment into sites of inflammation. The other two $\mathrm{T}$ helper subsets, $\mathrm{T}_{\mathrm{H}} 17$ and regulatory $\mathrm{T}$ cells $\left(\mathrm{T}_{\text {regs }}\right)$, specifically express CCR6 but not always by the $\mathrm{T}_{\mathrm{H}} 1$ or $\mathrm{T}_{\mathrm{H}} 2$ cells [19].

Research from different groups have conferred opposing roles to $\mathrm{T}_{\mathrm{H}} 17$ and regulatory $\mathrm{T}_{\text {reg }}$ cells in inflammatory disease [1]. IL-23 induced $\mathrm{T}_{\mathrm{H}} 17$ differentiation is known to promote inflammation and intriguingly $\mathrm{T}_{\mathrm{H}} 17$ also release CCL20, the chemokine ligand of CCR6. With either an autocrine or paracrine secretion of CCL20, $\mathrm{T}_{\mathrm{H}} 17$ cells also trigger a self-perpetuating cycle at inflammatory locations in a positive feedback loop. IL-17 production also induces TNF- $\alpha$ and IL-1 $\beta$, pointing towards an inflammatory pathway involving the nuclear transcription factor NF-kB [20]. FoxP3 ${ }^{+}$bearing regulatory $\mathrm{T}_{\text {reg }}$ cells are primarily disease suppressive in function and promote disease resolution by downregulating inflammatory T cell proliferation and is inducible through TGF- $\beta$ and IL-10 [21].

CCR6 expression on $\mathrm{T}_{\mathrm{H}} 17$ cells is induced through the cytokines, TGF- $\beta$, IL-6, IL-17, IL-21 and IL-23 as well as lineage- distinct, principal transcription factors ROR $\gamma t$ and ROR $\alpha$ [4]. CCL20 can be induced in a number of cell types by lipopolysaccharide (LPS) and also stimulated and up-regulated by the inflammatory cytokines IL- $1 \alpha$ and TNF $\alpha$ during acute inflammation. CCL20 expression is constitutively up-regulated by other inflammation- inducing cytokines, namely, IFN- $\gamma$ IL- $1 \beta$, IL-17, IL-21 [22]. In contrast, IL-10, which is anti-inflammatory, dampens CCL20 expression indicating that this chemokine does not very well favor the accumulation of regulatory $\mathrm{T}$ cells particularly at inflammatory locations. IL-4, IL-22 and surprisingly, IL-23 have reported insignificant stimulatory effects on CCL20 expression [4].

CCR6 confers an antagonistic function in these $\mathrm{T}$ helper populations, the $\mathrm{T}_{\mathrm{H}} 17$ and Treg cells, although it is unknown what other factors are responsible for tipping the balance in favor of disease progression. CCR6-CCL20 axis remains the pivotal point which determines reciprocal generation of these two cell types but simultaneously highlights the importance of CCR6 in T cell migration.

A disrupted CCR6-CCL20 axis only leads to the development of inflammation because CCR6 is adequately expressed on regulatory $\mathrm{T}$ cell populations in the cure phenotypes. A study involving the transfer of "wild type" $\mathrm{T}_{\mathrm{H}} 17$ cells and CCR6 deficient $\mathrm{T}$ cells into a "Rag1"/- severe combined immune deficient (SCID) mice" resulted in extreme intestinal inflammation and a subsequent reduction 
in $\mathrm{T}_{\mathrm{H}} 17$ and $\mathrm{T}_{\text {reg }}$ populations occurring [1]. CCR6 expression is deemed to be critical to $\mathrm{T}_{\text {reg }}$ cells than to $\mathrm{T}_{\mathrm{H}} 17$ cells, because this subset suppresses inflammatory $\mathrm{T}$ cell proliferation and promotes disease resolution. Research documented so far has assigned dual roles to CCR6 in inflammation and immune homeostasis [23].

\section{CCR6 Signaling Pathway}

CCR6 on leukocytes having bound to CCL20 initiates a signal transduction cascade via activation of the Gai subfamily of heterotrimeric G proteins. Synonymous with most of the classical chemokine receptors, the downstream signaling of CCR6 initiates activation of calcium mobilization, phospholipase, and phosphatidylinositol 3-kinase, followed by ERK1/2 phosphorylation and actin polymerization [24].

Cell responses to chemokines include natural sensitivity to pertussis toxin, which is an indication that the G1 class proteins are annexed to the signaling pathway downstream of the receptor. As explained by Figure 1, activated G protein, subsequent to releasing guanosine di phosphate (GDP)

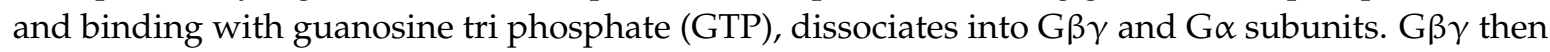
activates membrane-amalgamated phospholipase C- $\beta 2$ (PLC) and phosphoinositide 3-kinase (PI $\mathrm{K}_{3}$. $\mathrm{PI}_{3} \mathrm{~K}$ catalyzes phosphatidylinositol 4, 5 bi-phosphate $\left(\mathrm{PIP}_{2}\right)$ into phosphatidylinositol 4, 5 bi-phosphate $3\left(\mathrm{PIP}_{3}\right)$ which is next converted into inositol triphosphate $\left(\mathrm{IP}_{3}\right)$. Concomitantly diacylglycerol (DAG) is activated by PLC. $\mathrm{IP}_{3}$ regulates the mobilization of calcium ions from intracellular depots and DAG acts in resonance with calcium to activate different isoforms of protein kinase $C$ (PKC). Turned on PKC and various $\mathrm{Ca}$-innervated protein kinases catalyze phosphorylation, thereby activating successive signaling episodes which end up in cell migration [4].

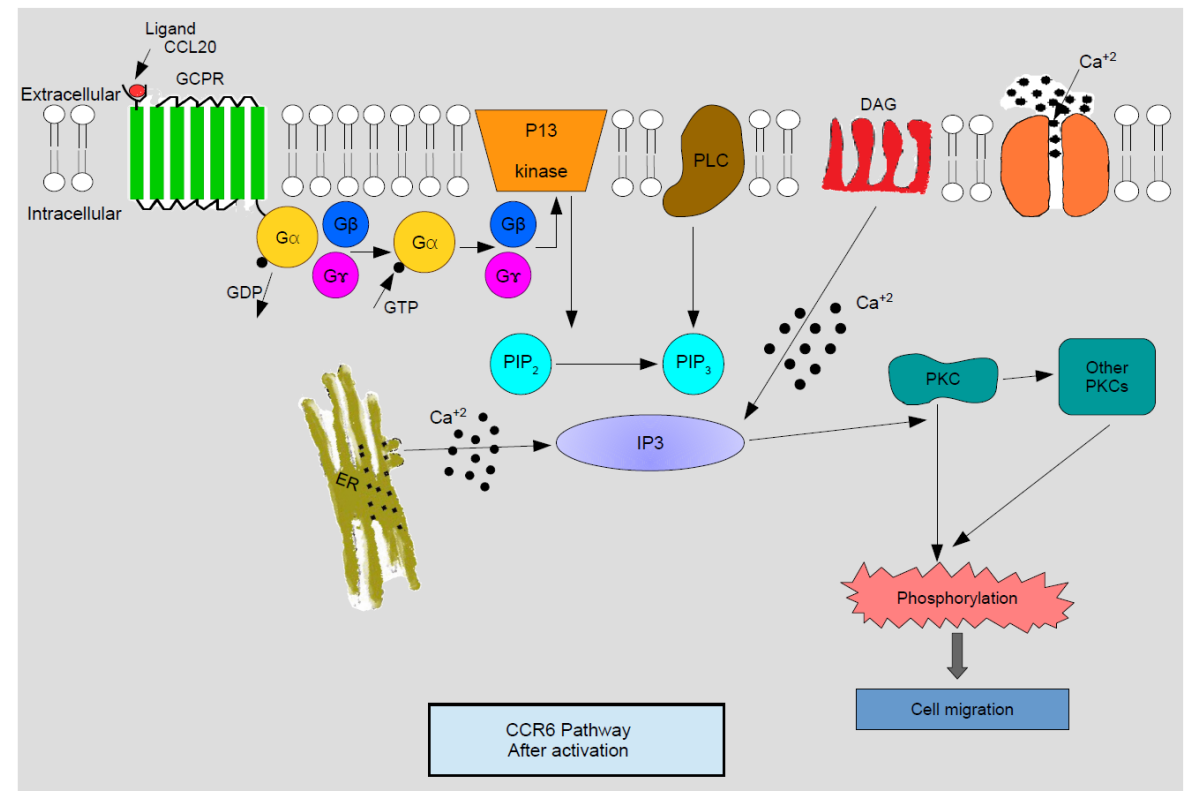

Figure 1. Schematic representation of C-C chemoattractant cytokine (chemokine) receptor 6 (CCR6) activation pathway. After binding with the ligand, G Protein Coupled Receptors (GPCR) are activated to release the G $\beta$ and $G \gamma$ subunits which in turn activate PLC and PI3 kinase. PI3 kinase then converts $\mathrm{PIP}_{2}$ to $\mathrm{PIP}_{3}$ which activates calcium ion mobilization across $\mathrm{IP}_{3}$. $\mathrm{IP}_{3}$ with DAG stimulated by calcium ions activate $\mathrm{PKC}$ and other PKCs which trigger phosphorylation causing cell migration. Legend for abbreviations: G $\alpha, G \beta, G \gamma$-Subunits of GPCR, PI3 kinase-Phosphoinositide 3 kinase, PLC-Phospholipase C $\beta 2$, DAG-diacylglycerol, PIP 2 -Phosphatidylinositol 4,5-bisphosphates, $\mathrm{PIP}_{3}$ - Phosphatidylinositol 4,5-bisphosphates 3, $\mathrm{IP}_{3}$-Inositol triphosphate, PKC - Protein kinase C, ER—endoplasmic reticulum, $\mathrm{Ca}^{+2}$ —Calcium ions. Reproduced from [4]. Copyright 2003, CRC Press: Boca Raton, FL, USA. 


\section{CCR6 and CCL20 in Health and Disease}

CCR6 and CCL20 have been implicated as potential manipulators which create a significant impact on human health and disease. In normal health, this pair performs an immune tolerance role by up-regulating immune suppression. When confronted with an inflammatory stimulus FoxP3 ${ }^{+}$ regulatory $\mathrm{T}_{\text {reg }}$ cells tend to proliferate aided by its cytokine milieu [25]. If this typical homeostatic function is disrupted, it is known to bring forth a marked increase of the $\mathrm{T}_{\mathrm{H}} 1 / \mathrm{T}_{\mathrm{H}} 17$ axis thereby promoting adverse immunologic function of multiple systems culminating in a number of diseases, namely, sarcoidosis, idiopathic pulmonary fibrosis, chronic liver disease, experimental autoimmune encephalomyelitis, multiple sclerosis, rheumatoid arthritis, dry eye disease, psoriasis, glomerular nephritis, inflammatory bowel disease, HIV and an array of malignant cancers and their metastasis as shown by both Table 1 and Figure 2.

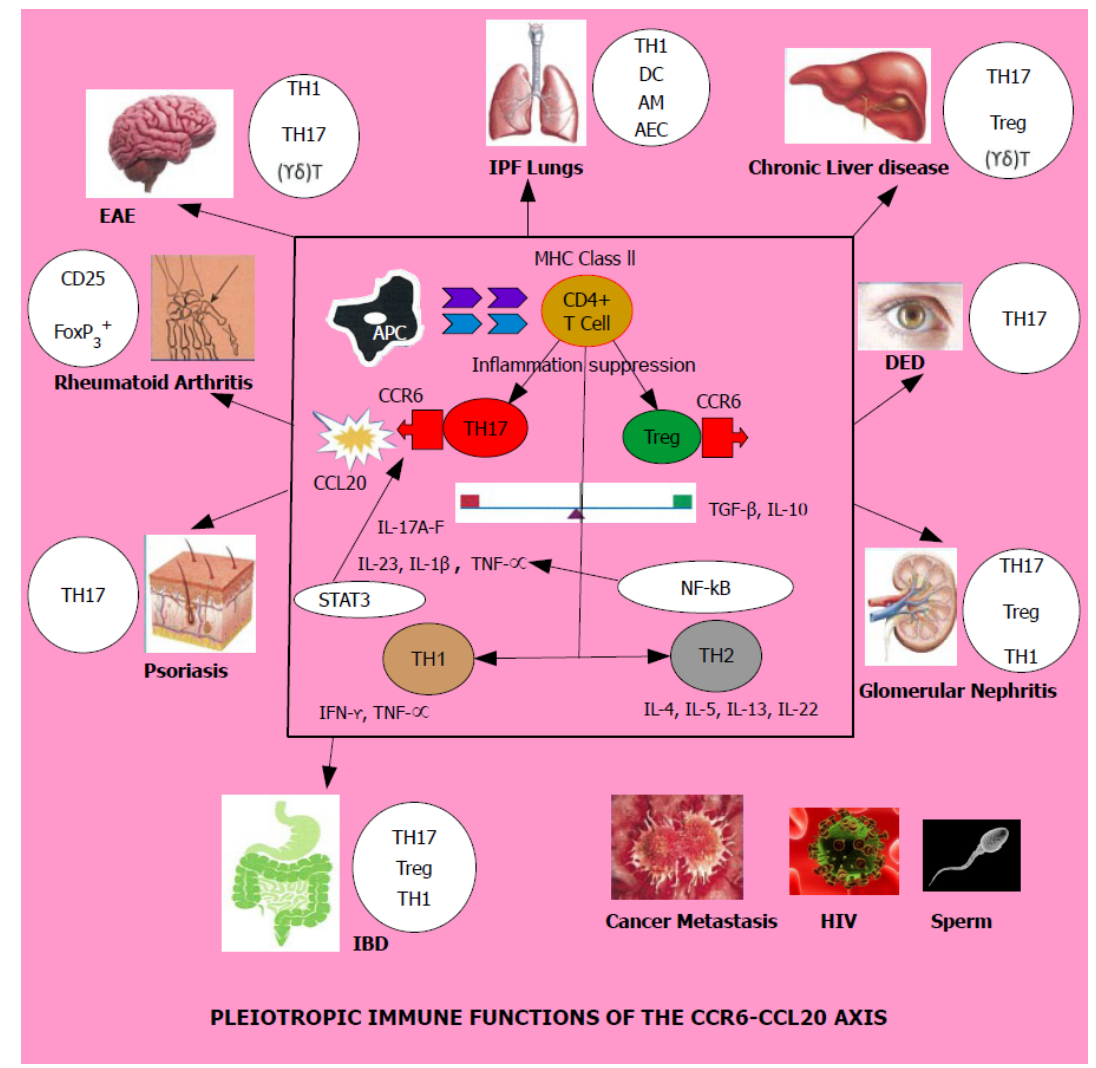

Figure 2. Schematic representation of the immunological impact of CCR6/CCL20 axis on multiple organs in the human body and the cells involved in promoting disease given next to each organ. EAE, IPF lungs, Chronic liver disease, DED, Rheumatoid arthritis, IBD, Psoriasis, Glomerular nephritis, HIV and Cancer metastasis are all diseases driven by the CCR6-CCL20 axis and disease progression leading to pathogenesis is promoted by $\mathrm{T}$ helper lymphocyte subsets, particularly $\mathrm{T}_{\mathrm{H}} 17$ and decrease in Treg cells. The factors which tilt the $\mathrm{T}_{\mathrm{H}} 17$-Treg balance influenced by transcription factors and cytokines in the tissue microenvironment is yet to be discovered. Legend for abbreviations: EAE-Experimental Autoimmune Encephalomyelitis, IPF lungs-Idiopathic Pulmonary Fibrosis lungs, DED—Dry Eye Disease, IBD—Inflammatory Bowel Disease, HIV—Human Immunodeficiency Virus, APC-Antigen Presenting Cell, MHC Class II-Major Histocompatibility Complex Class II, AM-Alveolar Macrophages, DC-Dendritic Cells, FB-Fibroblasts, AEC-Alveolar Epithelial Cells, CCR6-Chemokine receptor 6, CCL20-Chemokine ligand 20, IL-Interleukin, $\mathrm{T}_{\mathrm{H}} 1, \mathrm{~T}_{\mathrm{H}} 2$, $\mathrm{T}_{\mathrm{H}} 17, \mathrm{~T}_{\text {reg }}$-Regulatory $\mathrm{T}_{\text {reg }}$ cells- $\mathrm{T}$ helper lymphocyte subsets, $(\gamma \delta) \mathrm{T}$ cells-gamma delta $\mathrm{T}$ lymphocytes, NF-kB - nuclear factor kappa B, STAT3 — signal transducer and activator of transcription 3. TNF- $\alpha$-tumor necrosis factor-alpha. 


\subsection{Lung}

Adult human airways are not only a potential hub for harmful microbes, but are also exposed to allergens, pollutants, pulmonary emboli, complement deposition or autoantibodies, because the lungs are said to inhale around 10,000 $\mathrm{L}$ of air every $24 \mathrm{~h}$. A typical response to these onslaughts by lung injury is the localized synthesis and release of distinctive chemokines, which amplify the inflammatory response. Inflammation is considered necessary in one way to defend, repair, protect against or subdue an infection. Thus, activating leukocyte chemotaxis is vital to the development of antimicrobial host defense [4].

Research from Facco et al. on pulmonary sarcoidosis had revealed CCR6 expression on $\mathrm{T}_{\mathrm{H}} 1$ cells. CCR6 was co-expressed on alveolar macrophages in patients of sarcoidosis and alveolitis along with CXCR3 and CXCR6. CCR6 ${ }^{+} \mathrm{T}$ cells infiltrated into the lung interstitial tissue and were responsive to CCL20, CXCL10 and CXCL16. This observation amply demonstrates that T cells bearing CCR6 act in a coordinated manner with ligand and inflammatory cytokines produced by $\mathrm{T}_{\mathrm{H}} 1$ during alveolitic disease [25]. Further, CCR6 possesses the capability to recruit antigen-presenting immature and mature dendritic cells (DC) and macrophages to sites of inflammation on the alveolar epithelium [26].

CCL18, released by alternatively activated macrophages, induced collagen synthesis by human lung fibroblasts, indicating CCR6 as the receptor for CCL18, reported from a screened phage-display library. Staining lung tissue indicated CCR6 presence on alveolar epithelial cells II (AEC-II) and fibroblasts in idiopathic pulmonary fibrotic (IPF) lungs that blocks airways, but not in tumor-free areas of squamous cell carcinoma patients. It inferred a role for CCR6-CCL18 involving fibroblasts in human lung disease [12].

In contrast, gene delivery of human CCL18 to the lungs of wild type (WT) mice induced infiltration of T lymphocytes to the lungs, but the expression of CCR6 was found to be below $5 \%$ in the lymphocyte population. In the lungs of CCR6 knockout mice, CCL18-driven T lymphocyte trafficking was reduced but not completely halted. These observations, made in vivo in mice, concluded that CCR6 was not required for CCL18-induced changes, and that CCR6 is not the principal receptor for CCL18 in this animal model [27].

\subsection{Kidney}

Glomerulonephritis is characterized by tissue damage caused due to T cell trafficking into the kidney. Chemokines modulate the migration of $\mathrm{T}$ lymphocytes to sites of inflammation. Renal FoxP3 ${ }^{+}$ regulatory $T$ cells $\left(T_{\text {reg }}\right)$ and IL-17 releasing $T_{H} 17$ cells were shown to upregulate CCR6 while IFN- $\gamma$ releasing $\mathrm{T}_{\mathrm{H}} 1$ cells were CCR6 negative. $\mathrm{T}_{\text {regs }}$ and $\mathrm{T}_{\mathrm{H}} 17$ subsets displayed migratory capability towards CCL20 which was markedly high in renal biopsies of experimental murine nephritis. T cell recruitment was followed by pathogenesis in the kidney with albuminuria, leading to loss of renal function [28]. Nephritic mice deficient in CCR6 demonstrated extreme renal damage and high mortality in comparison to the wild type, due to less accumulation of $\mathrm{T}_{\text {reg }}$ cells and $\mathrm{T}_{\mathrm{H}} 17$ cells and not that of the $\mathrm{T}_{\mathrm{H}} 1$ type. This suggests an imbalance of $\mathrm{T}_{\mathrm{reg}} / \mathrm{T}_{\mathrm{H}} 17$ paradigm associated with CCR6 mediation exists in the kidneys too, similar to the gut. Reintroduction of $\mathrm{WT} \mathrm{T}_{\text {reg }}$ had offered protection to CCR6 knockout mice against severe renal injury, confirming that CCR6 promotes the recruitment of both $T_{H} 17$ and regulatory $T$ reg cells to the kidney whereas a decrease in $T_{\text {regs }}$ in the presence of $T_{H} 1$ response produced aggravated disease [29]. $\mathrm{T}_{\text {regs }}$ have been implicated in maintaining tolerance to autoimmune renal disease, thereby lowering renal inflammation, and in preventing allogenic responses in renal transplantation [30].

CCR6 and CCL20 are reportedly involved in recruiting T and B cells to kidney nodules during chronic inflammation in individuals. The CCR6/CCL20 mRNA expression quantified in renal biopsies of various nephropathies had revealed this cognate chemokine receptor was expressed in a number of kidney-associated cells: $\mathrm{CD} 20^{+} \mathrm{B}$ cells, $\mathrm{CD}^{+} \mathrm{T}$ cells, tubular epithelial cells and the peritubular and glomerular capillary endothelial cells although the functional role of CCR6 in the renal endothelium had not been assessed. Similarly to CCR6-CCL20 acting as a mediator in the modelling 
of gut-associated lymphatic tissue, it is postulated that the nodular infiltrates in the kidney are also formed in a CCR6-dependent manner [31].

\subsection{Liver}

Chronic liver injury results from hepatic inflammation, leading to organ fibrosis. Intrahepatic increase in CCR6 and CCL20 expression was observed in patients with chronic liver disease compared to healthy controls. It demonstrated that this chemokine receptor ligand pair may contribute to the migration of gamma-delta $(\gamma \delta) \mathrm{T}$ cells, $\mathrm{T}_{\mathrm{H}} 17$ and regulatory $\left(\mathrm{T}_{\text {reg }}\right)$ cells to sites of inflammation. CCR6 was explicitly required by IL-17 expressing $\gamma \delta \mathrm{T}$ cells to gather in the injured liver and promote disease resolution. Immunohistochemistry revealed accumulation of mononuclear cells bearing CCR6 induced by CCL20 secretion of hepatic parenchymal tissue in clinical liver disease. Compared to the WT, CCR6 knockout mice developed more acute fibrosis with enhanced immune cell infiltration to the liver $[32,33]$.

\subsection{Brain}

$\mathrm{T}_{\mathrm{H}} 17$ is strongly associated with autoimmune diseases, as demonstrated by pre-clinical studies in rheumatoid arthritis and multiple sclerosis. Neutralizing IL-17 as well as transfer of $\mathrm{T}_{\mathrm{H}} 17$ lacking CCR6 receptors had markedly inhibited experimental autoimmune encephalomyelitis (EAE). Apart from autoimmune promoting, pro-inflammatory function of $\mathrm{T}_{\mathrm{H}} 17$ it is also known to bring about disease resolution. Chemokines and adhesion molecules activate $\mathrm{T}$ cells, propelling them to migrate towards the central nervous system (CNS). The choroid plexus constitutively express CCL20 and is thought to act as an entry point for CCR6 expressing $\mathrm{CD}^{+} \mathrm{T}$ cells. EAE in animal models is used to study multiple sclerosis, which is a demyelinating inflammatory disorder of the CNS and infiltrating $\mathrm{T}$ cells contribute to its pathogenesis. Effector $\mathrm{T}_{\mathrm{H}} 17$ and $\mathrm{T}_{\mathrm{H}} 1$ subsets are found in multiple sclerosis lesions along with the expression of cytokines IL-17 and IFN- $\gamma$. CCR6 demonstrates a critical aspect in the entry of $\mathrm{T}_{\mathrm{H}} 17$ which is said to induce EAE in the CNS. CNS-infiltrating cells, when analyzed directly for CCR6 expression, have revealed that in EAE, $\mathrm{T}_{\mathrm{H}} 1$ cells are in excess of $\mathrm{T}_{\mathrm{H}} 17 \mathrm{CD} 4^{+}$and both subtypes however, expressed CCR6 [34,35].

Cerebral ischemia or stroke is ranked the second globally most common cause of death and is a much-debilitating neurological disease condition. Immune-mediated tissue damage occurs in the first few days of suffering a stroke and is mainly attributed to brain-infiltrating, IL-17 releasing, $\gamma \delta \mathrm{T}$ cells which are largely positive for the chemokine receptor CCR6 as they trigger a highly conserved immune reaction. In a model of experimental stroke, genetic deficiency in Ccr6 was associated with diminished infiltration of natural IL-17 releasing $\gamma \delta$ T cells and a significantly improved neurological outcome, outlining the role CCR6 plays in pro-inflammatory immune cell chemotaxis to inflamed sites in the brain [36].

\subsection{Eye}

$\mathrm{T}_{\mathrm{H}} 17$ cells are the principal effector cells causing inflammation in dry eye disease (DED), an immune inflammatory condition affecting the ocular surface that can even lead to corneal perforation. Local neutralization of CCL20 with antibodies administered sub-conjunctively to DED mice had decreased $\mathrm{T}_{\mathrm{H}} 17$ cell permeation into the ocular surface producing improvement in clinical signs, suggesting that CCR6 interaction with CCL20 could direct the passage of $\mathrm{T}_{\mathrm{H}} 17$ cells in the eye. Inhibition of the CCR6/CCL20 axis is therefore projected as a novel therapeutic mechanism to treat this condition [37].

\subsection{Skin}

The skin disorder atopic dermatitis (AD) is identified by a deficiency of keratinocytes in the skin, which produces less CCL20, and similarly such patients also display a reduction in the expression of CCR6, which leaves them exposed to viral infections leading to eczema herpeticum (ADEH) or 
eczema vaccinatum (EV). A population-based study of European and African descent had recorded single nucleotide polymorphism (SNP) in CCL20 in native Europeans significantly associated with AD, suggesting that variants in CCL20 and CCR6 are highly relevant to AD and increase the risk of severe viral complications in this skin disease [38].

Psoriasis is a commonly occurring autoimmune skin disease that involves $\mathrm{T}_{\mathrm{H}} 17$ associated signaling pathways. CCR6 deficient mice had failed to develop psoriasiform dermatitis in skin following IL-23 injections, because IL-23 is a growth and differentiation factor of $\mathrm{T}_{\mathrm{H}} 17$ cells and hence a typical driver of $\mathrm{T}_{\mathrm{H}} 17$ mediated inflammation, validated by previous research showing that recombinant IL-23 injections given to mice skin results in psoriasiform dermatitis that mimics human psoriasis in as short a period as 5 days. A more recent experimental model has documented that dermal CCR6 ${ }^{+} \mathrm{T}_{\mathrm{H}} 17$ cells are sustained by IL-23 released from dendritic cells and these $\mathrm{T}_{\mathrm{H}} 17$ populations release IL-22 to stimulate epidermal hyperplasia through signal transducer and activator of transcription 3 (STAT3) mediated mechanisms in the human skin. Additionally, positive feedback was provided by epidermal and dermal production of CCL20, potentially recruiting more CCR6 expressing $\mathrm{T}$ cells or antigen presenting cells into inflamed psoriatic skin. Inhibition of CCR6 has been suggested to provide a possible therapeutic pathway to cure this disease $[39,40]$.

\subsection{Joints}

Rheumatoid arthritis causes chronic inflammation of the joints where chemokines regulate infiltration of synovial fluid by inflammatory cells. This autoimmune disease is characterized by the increased release of CCL20 and the buildup of CCR6 bearing mononuclear T cells in the joints. An arthritis-induced study model of $\mathrm{CCR} 6^{-/-}$mice had not exhibited any clinical signs consistent with disease compared to WT controls, but revealed that CD4 ${ }^{+} \mathrm{T}$ cells, $\mathrm{T}_{\mathrm{H}} 17$ cells and CD25 FoxP3 ${ }^{+}$regulatory T cells showed up-regulation of CCR6 with RANKL, which contributed towards disease, particularly osteoclastogenesis. A possible role in pathogenesis is thus highlighted in CCR6 in promoting inflammation at the joints [41-43]. Ccr6 single nucleotide polymorphisms (SNPs) have demonstrated diminished basal and ligand induced Gai protein signaling which predisposes individuals to diseases such as rheumatoid arthritis [44].

\subsection{Gonad}

Capacitated human sperm is said to exhibit a directional movement towards CCL20 having the CCR6 receptor localized in the tail and a recent study revealed modifications in motility parameters of spermatozoa in the presence of chemokines. In non-inflammatory conditions, chemokine receptor/ ligand interactions within the reproductive tracts of the both sexes are known to promote sperm motility and chemotaxis. Physiological reactions are thus mediated by CCR6 ligands in the male genitourinary system which extends beyond an inflammatory response, and this observation underpins its significance in clinical reproduction and also possibly in contraception [45].

\subsection{Gut}

Animal models of the past and present have identified: (i) genetic predisposition; (ii) the composition of associated microbiome; (iii) breakdown of innate immune barriers-disruption of the mucosal barrier due to decreased mucin synthesis, dysfunctional Toll-like and Nod-like receptor mediated pathways leading to increased pathogenicity, endoplasmic reticulum (ER) stress mediated apoptosis; (iv) deregulated adaptive immunity; and (v) a plethora of environmental factors, as multiple causes responsible for inflammatory disorders in the gastrointestinal tract (GI) and disruption of the CCR6/CCL20 axis, also as a significant contributing factor [46-49]. 
Table 1. Organ systems and the diseases in which CCR6/CCL20 axis is operative along with the cell types involved in the disease progression which express CCR6.

\begin{tabular}{ccccc}
\hline Organ & CCR6/CCL20 Axis & Cell Types Involved & Disease Produced & References \\
\hline Lung & Operative & Fibroblasts, $\mathrm{AEC}, \mathrm{DC}, \mathrm{T}_{\mathrm{H}} 1, \mathrm{AM}$ & IPFL, Sarcoidosis & {$[12,25,26]$} \\
Liver & Operative & $\mathrm{T}_{\mathrm{H}} 17, \mathrm{~T}_{\text {reg }},(\gamma \delta) \mathrm{T}$ cells & Chronic liver disease & {$[32,33]$} \\
Kidney & Operative & $\mathrm{T}_{\mathrm{H}} 1, \mathrm{~T}_{\mathrm{H}} 17, \mathrm{~T}_{\text {reg }}$ & Glomerular nephritis & {$[28-31]$} \\
Brain & Operative & $\mathrm{T}_{\mathrm{H}} 1, \mathrm{~T}_{\mathrm{H}} 17,(\gamma \delta) \mathrm{T}$ cells & EAE, Stroke & {$[34-36]$} \\
Eye & Operative & $\mathrm{T}_{\mathrm{H}} 17$ & Dry eye disease & {$[37]$} \\
Skin & Operative & $\mathrm{T}_{\mathrm{H}} 17$ & Psoriasis & {$[39,40]$} \\
Joints & Operative & $\mathrm{CD} 25^{-} \mathrm{FoxP}^{+}$ & Rheumatoid arthritis & {$[41-43]$} \\
Gut & Operative & $\mathrm{T}_{\mathrm{H}} 17, \mathrm{~T}_{\text {reg }}, \mathrm{T}_{\mathrm{H}} 1$ & IBD & {$[1,50-52]$} \\
\hline
\end{tabular}

GWAS have confirmed Ccr6 as a risk allele of GI tract infections, among the 200 or so susceptibility loci already identified. It confirms that infectious diseases of the gut exhibit gene dependency and also gives prominence to the CCR6/CCL20 axis as a potential risk factor which determines disease outcome. $\mathrm{T}_{\mathrm{H}} 17$ cells are directed to the small intestine by CCR6 upon immune induction and not only $\mathrm{T}_{\mathrm{H}} 17$, but also $\mathrm{FoxP}^{+}$regulatory Tregs are upregulated, given the fact that CCR6 performs dual functions with regards to these two helper $\mathrm{T}$ subsets in gut associated lymphoid tissue (GALT). Accumulation of $\mathrm{T}_{\mathrm{H}} 17$ cells in the spleen and bone marrow in CCR6 deficient mice showed they were unable to migrate due to the absence of this receptor, and hence produced less intestinal inflammation. This fact further supports its role in directing immune cell movement in the gut and confirms that $\mathrm{T}_{\mathrm{H}} 17$ plays a pro-inflammatory role in intestinal disorders [50-52].

Intestinal microbiome which comprises of around 100 trillion cells is important for: (i) colonization and maintenance of immune cells; (ii) $\mathrm{T}_{\mathrm{H}} 17$-Treg balance in the gut; and (iii) protection against intestinal pathogens, evidenced by a reduction in $\mathrm{T}_{\mathrm{H}} 17$ and elevated Treg populations in mice given: (i) antibiotics; and (ii) bred in germ-free conditions. The disease outcome therefore primarily depends upon the CCR6-CCL20 axis, with microbiota featuring as another additional contributor [53,54].

Inflammatory bowel disease (IBD), which is an autoimmune GI tract disorder, consists of two clinical variants, Crohn's disease and Ulcerative colitis. A Ccr6 knockout murine models had displayed: (i) smaller Peyer's patches; (ii) reduced sub epithelial domes; (iii) absence of isolated lymphoid follicles; (iv) reduced intestinal $\mathrm{M}$ cell numbers; (v) increased resistance to bacteria which enters through $\mathrm{M}$ cell conduits; (vi) marked elevation in the number of $\mathrm{T}_{\mathrm{H}} 17$ cells in the spleen and lymph nodes; (vii) Reduced migration to inflamed sites and less suppressive capabilities of Treg cells; (viii) moderate and severe disease in DSS and TNBS induced colitis respectively; and (ix) transfer of naïve T cells to Rag2 ${ }^{-/-}$mice resulting in aggravated disease [55-57]. SNPs in Ccr6 have been reported to predispose individuals to Crohn's disease [44].

\subsection{Cancer}

Chemokines are utilized by cancer cells to directly invade the lymphatic system and spread via blood, as well as determine the location of metastatic growth of various tumors. CCL20 has been reportedly expressed in varied human cancer types, such as melanoma, adenocarcinoma, hepatocellular carcinoma leukemia, lymphoma, prostate cancer, colorectal, oral and lung squamous cell carcinoma and pancreatic carcinoma (PCA) $[58,59]$. The CCL20/CCR6 system has been demonstrated within pancreatic cancer cell lines and PCA-associated tissues. The stimulation of PCA cells expressing CCR6 with CCL20 had constitutively triggered cell proliferation, tendency to migrate and invasion of tissues indicating that CCL20 could act using mechanisms of autocrine and paracrine secretion. Recent studies have identified matrix metalloproteinase production to up-regulate CCL20, which promotes pancreatic tumor cell movement and their metastatic invasion [58].

A new interesting theme that involves chemokine receptor function is that chemokine receptors are equipped to drive cancer metastasis. Similar to CCR7 being useful for the movement of T cells within lymph nodes, when chemokine receptors are expressed in tumor cells, they may direct 
organ-targeted tumor metastasis. Precise signals which exist on the tumor cell surface, along with the establishment of chemotactic gradients, will allow them to migrate to metastatic destinations of numerous cancers. Various chemokine ligands have been strongly identified in directing metastasis into lymph nodes [59-61].

The chemokine superfamily is said to provide a useful target to find new important drugs because G protein coupled receptors (GPCR) are ideal for testing small molecular inhibitors, and therefore many best-selling anti-cancer therapeutics in the market today have targeted GPCR [62,63]. CCR6 inhibition in patients undergoing surgical treatment or clinical therapy has been proposed to be important to prevent liver metastasis of cancer, by a study of BALB/c mice. They showed overexpression of functional CCR6 and CCR7 on metastatic tumor cell lines obtained from the liver. Cell migration was studied employing green fluorescent protein-labelled metastatic cells and CCR6 mRNA was measured by RT-PCR. Results displayed preferential colonization of liver-sorted tumor cells when pre-incubated with the CCR6 ligand, which is constitutively expressed by hepatocytes. This demonstrates that CCR6 directs and drives the mechanisms of chemotaxis, commonly adopted by malignant cancers when metastasizing to the liver [33]. Mutations in Ccr6 also have been associated with a case of mucosa-associated lymphoid tissue (MALT) lymphoma [64].

\subsection{HIV}

Preferential infection by HIV of CCR6 ${ }^{+} \mathrm{T}_{\mathrm{H}} 17$ cells in vitro has been described in a study which had cultured both $\mathrm{T}_{\mathrm{H}} 1$ and $\mathrm{T}_{\mathrm{H}} 17$ cells obtained from peripheral blood of healthy individuals in the presence of activated IL-1 $\beta$ and IL-23. IL-23 was added to promote the expansion of $\mathrm{T}_{\mathrm{H}} 17$ cells. Infection by HIV had produced negligible effects on $\mathrm{T}_{\mathrm{H}} 1$ whilst causing a significant reduction in $\mathrm{T}_{\mathrm{H}} 17$ cells, increased infection of $\mathrm{T}_{\mathrm{H}} 17$ cells and cell death. It reportedly demonstrated a possible role for CCR6 in the internalizing of the virus within $\mathrm{T}$ helper populations [65]. In a more recent observation in relation to $\mathrm{HIV}$ infection of $\mathrm{T}_{\mathrm{H}} 17$ cells, CCR6 was presented as a weak alternative sub-receptor alongside the receptors CXCR4 and CCR5, which may provide an entry route to HIV invading the $\mathrm{T}$ helper cell subsets. This fact suggests that preferential infection of $\mathrm{T}$ cells takes place without CCR6 mediation. Yet, the importance of the CCR6/CCL20 axis is by no way diminished in HIV pathogenesis because this receptor- ligand pair is deemed to be actively recruiting $\mathrm{T}_{\mathrm{H}} 17$ cells and DCs to infection sites, thus helping the virus to propagate to other locations of the body [66]. Envelope surface glycoprotein gp120 is known to significantly promote the CCR6 expression on human B cells [11].

\subsection{Obesity and Diabetes}

The CCR6-CCL20 alliance is said to promote inflammation, leading to pathophysiological malignancies such as obesity and diabetes. Minor inflammation of the adipose tissue has been linked with obesity and is tactically driven via the CCR6-CCL20 axis. Adipose tissue lymphocytes expressing CCR6 have demonstrated chemotactic migration towards mature adipocytes which upregulate the chemokine ligand CCL20. Strongly enhanced CCL20 expression by adipocytes displayed a positive correlation with the body mass index (BMI), in visceral adipose tissue compared to the subcutaneous fat layers [67].

Increased leukocyte streaming into pancreatic islets causes inflammation in the beta cell mass influencing apoptosis and dysfunction. A study by Burke et al. had identified elevation of CCL20 levels in pancreatic beta cells induced by the transcriptional factor nuclear factor kappa B (NF-kB). They suggested intervening at the NF-kB -mediated chemokine upregulation, to disrupt the CCR6-CCL20 axis, which could become a therapeutic mechanism to negate inflammation-triggered dysfunction seen in both obese and diabetic individuals. T cell immunity is suppressed by the activation of type III histone deacetylase Sirtuin 1, which is known to regulate cellular processes via the SIRT1 gene. Resveratrol is a Sirtuin-1 activator which demonstrated therapeutic efficacy in a Nucleotide-binding and oligomerization domain (NOD) mouse model of type 1 diabetes. Resveratrol-treated mice 
exhibited a significant decrease in $C c r 6$ in a gene array analysis, correlating with decreased migration in $\mathrm{CCR}^{+}$macrophages and IL-17 producing cells into the pancreas from pancreatic lymph nodes $[68,69]$.

\section{Conclusions}

The CCR6/CCL20 axis thus demonstrates a vital role in determining the disease outcome of inflammatory disorders and cancer metastasis in multiple organ systems in the human body. Inhibition of the CCR6/CCL20 axis is expected to open up new vistas for discovering novel therapeutics in the treatment of human disorders, and a variety of therapeutic antibodies have already been made against the chemokine receptor 6. Effective blocking of the CCR6 signal transduction pathway using novel biochemical interventions might prove to be a useful therapeutic strategy in regulating pro-disease inducing cell chemotaxis within inflammatory microenvironments. Most of the research has been centered on animal models which do not depict the true clinical picture, therefore there remains an urgent need for the evaluation of this chemokine receptor 6 and its ligand pair in expanded in vivo and ex vivo clinical studies.

Funding: The first author is funded by a research training program (RTP) scholarship given by the Australian Government.

Conflicts of Interest: The authors declare no conflict of interests.

\section{References}

1. Lee, A.Y.S.; Eri, R.; Lyons, A.B.; Grimm, M.C.; Korner, H. CC chemokine ligand CCL20 and its cognate receptor CCR6 in mucosal T cell immunology and inflammatory bowel disease: Odd couple or axis of evil? Front. Immunol. 2013, 4, 194-206. [CrossRef] [PubMed]

2. Griffith, J.W.; Sokol, C.L.; Luster, A.D. Chemokines and chemokine receptors: Positioning cells for host defense and immunity. Annu. Rev. Immunol. 2014, 32, 659-702. [CrossRef] [PubMed]

3. Basheer, W.; Kunde, D.; Eri, R. Role of chemokine ligand CCL20 and its receptor CCR6 in intestinal inflammation. Immunol. Infect. Dis. 2013, 1, 30-37. [CrossRef]

4. Strieter, R.M.; Kunkel, S.L.; Standiford, T. Chemokines in the Lung; Lenfant, C., Ed.; Lung Biology in Health and Disease; CRC Press: Boca Raton, FL, USA, 2003; pp. 1-341.

5. Lee, A.Y.; Phan, T.K.; Hulett, M.D.; Korner, H. The relationship between CCR6 and its binding partners: Does the CCR6-CCL20 axis have to be extended? Cytokine 2015, 72, 97-101. [CrossRef] [PubMed]

6. Frick, V.O.; Rubie, C.; Keilholz, U.; Ghadjar, P. Chemokine/chemokine receptor pair CCL20/CCR6 in human colorectal malignancy: An overview. World J. Gastroenterol. 2016, 22, 833-841. [CrossRef] [PubMed]

7. Williams, I.R. CCR6 and CCL20: Partners in intestinal immunity and lymphorganogenesis. Ann. N. Y. Acad. Sci. 2006, 1072, 52-61. [CrossRef] [PubMed]

8. Bannan, J. The Role of the CC-Chemokine Receptor 6 in B Cell Differentiation during the Humoral Immune Response. Ph.D. Thesis, University of Tasmania, Hobart, Australia, 2014.

9. Zlotnik, A.; Yoshie, O.; Nomiyama, H. The chemokine and chemokine receptor super families and their molecular evolution. Genome Biol. 2006, 7, 243. [CrossRef] [PubMed]

10. Proudfoot, A.E. Chemokine receptors: Multifaceted therapeutic targets. Nat. Rev. Immunol. 2002, 2, 106-115. [CrossRef] [PubMed]

11. National Centre for Biotechnlogy Information. CCR6 C-C Motif Chemokine Receptor 6 (Human); US National Library of Medicine: Bethesda, MD, USA, 2018.

12. Zissel, G.; Hohne, K.; Kilic, A.; Maier, C.; Ploenes, T.; Prasse, A.; Trepel, M.; Eibel, H.; Muller-Quernheim, J. CCR6 is a receptor for CCL18 expressed on human lung fibroblasts from IPF lungs. Eur. Respir. J. 2011, 38 (Suppl. 55), 3232.

13. Lafferty, M.K.; Sun, L.; Christensen-Quick, A.; Lu, W.; Garzino-Demo, A. Human Beta Defensin 2 Selectively Inhibits HIV-1 in Highly Permissive CCR6 ${ }^{+} \mathrm{CD}^{+}{ }^{+} \mathrm{T}$ Cells. Viruses 2017, 9, 111. [CrossRef] [PubMed]

14. Ravindran, R.; Rusch, L.; Itano, A.; Jenkins, M.K.; McSorley, S.J. CCR6-dependent recruitment of blood phagocytes is necessary for rapid CD4 T cell responses to local bacterial infection. Proc. Natl. Acad. Sci. USA 2007, 104, 12075-12080. [CrossRef] [PubMed] 
15. Nandi, B.; Pai, C.; Huang, Q.; Prabhala, R.H.; Munshi, N.C.; Gold, J.S. CCR6 the sole receptor for the chemokine CCL20 promotes spontaneous intestinal tumorigenesis. PLoS ONE 2014, 9, e97566. [CrossRef] [PubMed]

16. Wiede, F.; Fromm, P.D.; Comerford, I.; Kara, E.; Bannan, J.; Schuh, W.; Ranasinghe, C.; Tarlinton, D.; Winkler, T.; McColl, S.R.; et al. CCR6 is transiently upregulated on B cells after activation and modulates the germinal centre reaction in the mouse. Immunol. Cell Biol. 2013, 91, 335-339. [CrossRef] [PubMed]

17. Comerford, I.; Bunting, M.; Fenix, K.; Haylock-Jacobs, S.; Litchfield, W.; Harata-Lee, Y.; Turvey, M.; Brazzatti, J.; Gregor, C.; Nguyen, P.; et al. An immune paradox: How can the same chemokine axis regulate both immune tolerance and activation? CCR6/CCL20: A chemokine axis balancing immunological tolerance and activation in autoimmune disease. Bioessays 2010, 32, 1067-1076. [CrossRef] [PubMed]

18. Schutyser, E.; Struyf, S.; Van Damme, J. The CC chemokine CCL20 and its receptor CCR6. Cytokine Growth Factor Rev. 2003, 14, 409-426. [CrossRef]

19. Varona, R.; Villares, R.; Carramolino, L.; Gova, I.; Gutierrez, J.; Torres, M.; Martinez-A, C.; Marquez, G. CCR6 deficient mice have impaired leukocyte homeostasis and altered contact hypersensitivity and delayed type hypersensitivity responses. J. Clin. Investig. 2001, 107, R37-R45. [CrossRef] [PubMed]

20. Zimmerman, N.P.; Vongsa, R.A.; Wendt, M.K.; Dwinell, M.B. Chemokines and chemokine receptors in mucosal homeostasis at the intestinal epithelial barrier in inflammatory bowel disease. Inflamm. Bowel Dis. 2008, 14, 1000-1011. [CrossRef] [PubMed]

21. Elgueta, R.; Marks, E.; Nowak, E.; Menezes, S.; Benson, M.; Raman, V.S.; Ortiz, C.; O'Connell, S.; Hess, H.; Lord, G.M.; et al. CCR6 dependent positioning of memory B cells is essential for their ability to mount a recall response to antigen. J. Immunol. 2015, 194, 505-513. [CrossRef] [PubMed]

22. Luegering, A.; Mead, J.; Hudson, J.T., III; Kucharzik, T.; Williams, I. CCR6 deficient mice with increased numbers of $\alpha \beta$ TCR intestinal intraepithelial lymphocytes exhibit enhanced innate immunity to infection with the nematode Heligmosomoides polygyrus. Gastroenterology 2003, 124 (Suppl. 1), A339. [CrossRef]

23. Jiang, S. (Ed.) Th17 Cells in Health and Disease; Springer Science and Business Media: New York, NY, USA, 2011; ISBN 978-1-4419-9371-7. [CrossRef]

24. Lu, M.Y.; Lu, S.S.; Chang, S.L.; Liao, F. The Phosphorylation of CCR6 on Distinct Ser/Thr Residues in the Carboxyl Terminus Differentially Regulates Biological Function. Front. Immunol. 2018, 9, 415. [CrossRef] [PubMed]

25. Facco, M.; Baesso, I.; Miorin, M.; Bortoli, M.; Cabrelle, A.; Boscaro, E.; Gurrieri, C.; Trentin, L.; Zambello, R.; Calabrese, F.; et al. Expression and role of CCR6/CCL20 chemokine axis in pulmonary sarcoidosis. J. Leukoc. Biol. 2007, 82, 946-955. [CrossRef] [PubMed]

26. Ito, T.; Carson, W.F., 4th; Cavassani, K.A.; Connett, J.M.; Kunkel, S.L. CCR6 as a mediator of immunity in the lung and gut. Exp. Cell Res. 2011, 317, 613-619. [CrossRef] [PubMed]

27. Luzina, I.G.; Atamas, S.P. CCR6 is not necessary for functional effects of human CCL18 in a mouse model. Fibrogenes. Tissue Repair 2012, 5, 2. [CrossRef] [PubMed]

28. Turner, J.; Paust, H.J.; Steinmetz, O.M.; Peters, A.; Riedel, J.H.; Erhardt, A.; Wegscheid, C.; Velden, J.; Fehr, S.; Mittrucker, H.W.; et al. CCR6 recruits regulatory T cells and TH17 cells to the kidney in glomerularnephritis. J. Am. Soc. Nephrol. 2010, 21, 974-985. [CrossRef] [PubMed]

29. Welsh-Bacic, D.; Lindenmeyer, M.; Cohen, C.D.; Draganovici, D.; Mandelbaum, J.; Edenhofer, I.; Ziegler, U.; Regele, H.; Wuthrich, R.P.; Segerer, S. Expression of the chemokine receptor CCR6 in human renal inflammation. Nephrol. Dial. Transpl. 2011, 26, 1211-1220. [CrossRef] [PubMed]

30. Alikhan, M.A.; Huynh, M.; Kitching, A.R.; Ooi, J.D. Regulatory T cells in renal disease. Clin. Transl. Immunol. 2018, 7, e1004. [CrossRef] [PubMed]

31. Chung, A.C.; Lan, H.Y. Chemokines in renal injury. J. Am. Soc. Nephrol. 2011, 22, 802-809. [CrossRef] [PubMed]

32. Hammerich, L.; Bangen, J.M.; Govaere, O.; Zimmermann, H.W.; Gassler, N.; Huss, S.; Liedtke, C.; Prinz, I.; Lira, S.A.; Luedde, T.; et al. Chemokine Receptor CCR6-Dependent Accumulation of gamma delta T Cells in Injured Liver Restricts Hepatic Inflammation and Fibrosis. Hepatology 2014, 59, 630-642. [CrossRef] [PubMed]

33. Dellacasagrande, J.; Schreurs, O.J.F.; Hofgaard, P.O.; Omholt, H.; Steinsvoll, S.; Schenck, K.; Bogen, B.; Dembic, Z. Liver metastasis of cancer facilitated by chemokine receptor CCR6. Scand J. Immunol. 2003, 57, 534. [CrossRef] [PubMed] 
34. Ransohoff, R.M.; Trettel, F. Chemokines and chemokine receptors in brain homeostasis. Front. Cell. Neurosci. 2015, 9, 132. [CrossRef] [PubMed]

35. Robert, R.; Ang, C.; Sun, G.; Juglair, L.; Lim, F.X.; Mason, L.J.; Payne, N.L.; Bernard, C.C.A.; Mackay, C.R. Essential role for CCR6 in certain inflammatory diseases demonstrated using specific antagonist and knockin mice. JCI Insight 2017, 2, e94821. [CrossRef] [PubMed]

36. Arunachalam, P.; Ludewig, P.; Melich, P.; Arumugam, T.V.; Gerloff, C.; Prinz, I.; Magnus, T.; Gelderblom, M. CCR6 (CC Chemokine Receptor 6) is essential for the migration of detrimental natural interleukin-17-Producing $\gamma \delta \mathrm{T}$ cells in stroke. Stroke 2017, 48, 1957-1965. [CrossRef] [PubMed]

37. Dohlman, T.H.; Chauhan, S.K.; Kodati, S.; Hua, J.; Chen, Y.; Omoto, M.; Sadrai, Z.; Dana, R. The CCR6/CCL20 axis mediates Th17 cell migration to the ocular surface in dry eye disease. Investig. Opthalmol. Vis. Sci. 2013, 54, 4081-4091. [CrossRef] [PubMed]

38. Rafaels, N.M.; Beck, L.A.; Gao, P.S.; Hand, T.; Boguniewicz, M.; Hata, T.R.; Schneider, L.; Hanifin, J.M.; Gallo, R.L.; Gao, L.; et al. Variations in the CCL20 and CCR6 Genes are Associated with Atopic Dermatitis and Eczema Herpeticum in Populations of European and African descent. J. Allergy Clin. Immunol. 2009, 123, S70. [CrossRef]

39. Hedrick, M.N.; Lonsdorf, A.S.; Hwang, S.T.; Farber, J.M. CCR6 as a possible therapeutic target in psoriasis. Expert Opin. Ther. Targets 2010, 14, 911-922. [CrossRef] [PubMed]

40. Hwang, S.T. Function and Targeting of CCR6/CCL20 in Autoimmune Psoriasiform; National Institute of Health: Bethesda, MD, USA, 2017; Available online: grantome.com/grant/NIH/R01-AR063091-01A1 (accessed on 25 May 2018).

41. Bonelli, M.; Puchner, A.; Goeschl, L.; Hayer, S.; Smolen, J.; Scheinecker, C.; Bluml, S. CCR6 expression drives arthritis in a T cell dependent manner [abstract]. In Proceedings of the 2016 ACR/ARHP Annual Meeting, Washington, DC, USA, 11 November 2016; Available online: http:/ /acrabstracts.org/abstract/ccr6expression-regulates-arthritis-in-a-t-cell-dependent-manner/ (accessed on 25 May 2018).

42. Bonelli, M.; Goeschl, L.; Puchner, A.; Bluml, S. CCR6 modulates severity of arthritis in T cell dependent manner. BMJ J. 2017, 76 (Suppl. 1). [CrossRef]

43. Dairaghi, D.; Zhang, P.; Leleti, M.; Berahovich, R.; Ebsworth, K.; Ertl, L.; Miao, S.; Miao, Z.; Seitz, L.; Tan, J.; et al. Inhibition of Chemokine Receptors CCR1 and CCR6 as Promising Therapies for Autoimmune Diseases such as Rheumatoid Arthritis and Psoriasis. In Proceedings of the 2013 ACR/ARHP Annual Meeting in Annals of the Rheumatic Diseases, San Diego, CA, USA, 25-30 October 2013; Volume 72.

44. Julian, B.; Gao, K.; Harwood, B.N.; Beinborn, M.; Kopin, A.S. Mutation-induced functional alterations of CCR6. J. Pharmacol. Exp. Ther. 2017, 360, 106-116. [CrossRef] [PubMed]

45. Caballero-Campo, P.; Buffone, M.G.; Benencia, F.; Conejo-Garcia, J.R.; Rinaudo, P.F.; Gerton, G.L. A Role for the Chemokine Receptor CCR6 in mammalian sperm motility and chemotaxis. J. Cell. Physiol. 2013, 229, 68-78. [CrossRef] [PubMed]

46. Varona, R.; Cadenas, V.; Flores, J.; Martinez-A, C.; Marquez, G. CCR6 has a non redundant role in the development of inflammatory bowel disease. Eur. J. Immunol. 2003, 33, 2937-2946. [CrossRef] [PubMed]

47. Skovdhal, H.K.; Granlund, A.V.; Ostvik, A.E.; Bruland, T.; Bakke, J.; Torp, S.H.; Damas, J.K.; Sandvik, A.K. Expression of CCL20 and its corresponding receptor CCR6 is enhanced in active inflammatory bowel disease and TLR3 mediates CCL20 expression in colonic epithelial cells. PLOS ONE 2015, 10, e0141710. [CrossRef] [PubMed]

48. Shouval, D.S.; Rufo, P.A. The role of environmental factors in the pathogenesis of inflammatory bowel diseases: A review. JAMA Pediatr. 2017, 171, 999-1005. [CrossRef] [PubMed]

49. Cader, M.Z.; Kaser, A. Recent advances in inflammatory bowel disease: Mucosal immune cells in intestinal inflammation. Gut 2013, 62, 1653-1664. [CrossRef] [PubMed]

50. Lee, S.H.; Kwon, J.; Cho, M. Immunological pathogenesis of inflammatory bowel disease. Intest. Res. 2018, 16, 26-42. [CrossRef] [PubMed]

51. Fakhoury, M.; Negruli, R.; Mooranian, A.; Al-Salami, H. Inflammatory bowel disease: Clinical aspects and treatments. J. Inflamm. Res. 2014, 7, 113-120. [CrossRef] [PubMed]

52. Pedros, C.; Duguet, F.; Saoudi, A.; Chabod, M. Disrupted regulatory T cell homeostasis in inflammatory bowel disease. World J. Gastroenterol. 2016, 22, 974-995. [CrossRef] [PubMed]

53. Korn, T.; Bettelli, E.; Oukka, M.; Kuchroo, V.K. IL-17 and Th17 cells. Annu. Rev. Immunol. 2009, 27, 485-517. [CrossRef] [PubMed] 
54. Muzes, G.; Molnar, B.; Tulassay, Z.; Sipos, F. Changes of the cytokine profile in inflammatory bowel diseases. World J. Gastroenterol. 2012, 18, 5848-5861. [CrossRef] [PubMed]

55. Eri, R.; McGuckin, M.A.; Wadley, R. T cell transfer model of colitis: A great tool to assess the contribution of T cells in chronic intestinal inflammation. Methods Mol. Biol. 2012, 844, 261-275. [CrossRef] [PubMed]

56. Raza, A.; Yousaf, W.; Giannella, R.; Shata, M.T. Th17 cells interactions with predisposing factors of immunopathogenesis of inflammatory bowel disease. Expert Rev. Clin. Immunol. 2012, 8, 161-168. [CrossRef] [PubMed]

57. Westphal, S.; Lugering, A.; von Wedel, J.; von Eiff, C.; Maaser, C.; Spahn, T.; Heusipp, G.; Schmidt, M.A.; Herbst, H.; Williams, I.R.; et al. Resistance of chemokine receptor 6-deficient mice to Yersinia enterocolitica infection: Evidence of defective M-cell formation in vivo. Am. J. Pathol. 2008, 172, 671-680. [CrossRef] [PubMed]

58. Rubie, C.; Frick, V.O.; Ghadjar, P.; Wagner, M.; Grimm, H.; Vicinus, B.; Justinger, C.; Graeber, S.; Schilling, M.K. CCL20/CCR6 expression profile in pancreatic cancer. J. Transl. Med. 2010, 8, 45. [CrossRef] [PubMed]

59. Chang, H.; Wei, J.W.; Tao, Y.L.; Ding, P.R.; Xia, Y.F.; Gao, Y.H.; Xiao, W.W. CCR6 is a predicting biomarker of radiosensitivity and potential target of radiosensitization in rectal cancer. Cancer Res. Treat 2017. [CrossRef] [PubMed]

60. Martin-Garcia, D.; Lonsdorf, A.; Enk, A. Characterization and modulation of CC-chemokine receptor 6 (CCR6) and CC ligand 20 (CCL20)-Mediated immunosurveillance in malignant melanoma. J. Investig. Dermatol. 2017, 137, S289. [CrossRef]

61. Ikeda, S.; Kitadate, A.; Ito, M.; Abe, F.; Nara, M.; Watanabe, A.; Takahashi, N.; Miyagaki, T.; Sugaya, M.; Tagawa, H. Disruption of CCL20-CCR6 interaction inhibits metastasis of advanced cutaneous T cell lymphoma. Oncotarget 2016, 7, 13563-13574. [CrossRef] [PubMed]

62. Boyle, S.T.; Faulkner, J.W.; McColl, S.R.; Kochetkova, M. The chemokine receptor CCR6 facilitates the onset of mammary neoplasia in the MMTV-PyMT mouse model via recruitment of tumor-promoting macrophages. Mol. Cancer 2015, 14, 115. [CrossRef] [PubMed]

63. Li, Y.; Huang, J.; Tie, H.; Huang, H.; Li, H.; Ren, G. Prognostic significance of CCL20 and its receptor CCR6 in cancers: A meta-analysis. Int. J. Clin. Exp. Med. 2016, 9, 1908-1919.

64. Moody, S.; Thompson, J.S.; Chuang, S.S.; Liu, H.; Raderer, M.; Vassiliou, G.; Wlodarska, I.; Wu, F.; Cogliatti, S.; Robson, A.; et al. Novel GPR34 and CCR6 mutation and distinct genetic profiles in MALT lymphomas of different sites. Haematologica 2018. [CrossRef] [PubMed]

65. Lee, A.Y.S.; Korner, H. CCR6/CCL20 chemokine axis in human immunodeficiency virus immunity and pathogenesis. J. Gen. Virol. 2017, 98, 338-344. [CrossRef] [PubMed]

66. Alvarez, Y.; Tuan, M.; Nawaz, F.; Arthos, J.; Wolff, M.J.; Poles, M.A.; Hioe, C.E. Preferential HIV infection of CCR6+ Th17 cells is associated with higher levels of virus receptor expression and lack of CCR5 ligands. J. Virol. 2013, 87, 10843-10854. [CrossRef] [PubMed]

67. Duffaut, C.; Zakaroff-Girard, A.; Bourlier, V.; Decaunes, P.; Maumus, M.; Chiotasso, P.; Sengenes, C.; Lafontan, M.; Galitzky, J.; Bouloumie, A. Interplay between human adipocytes and T lymphocytes in obesity: CCL20 as an adipochemokine and T lymphocytes as lipogenic modulators. Arterioscler. Thromb. Vasc. Biol. 2009, 29, 1608-1614. [CrossRef] [PubMed]

68. Burke, S.J.; Karlstad, M.D.; Regal, K.M.; Sparer, T.E.; Lu, D.; Elks, C.M.; Grant, R.W.; Stephens, J.M.; Burk, D.H.; Jason, C.J. CCL20 is elevated during obesity and differentially regulated by NF-kB subunits in pancreatic $\beta$-cells. Biochim. Biophys. Acta 2015, 1849, 637-652. [CrossRef] [PubMed]

69. Lee, S.M.; Yang, H.; Tartar, D.M.; Gao, B.; Luo, X.; Ye, S.Q.; Zaghouani, H.; Fang, D. Prevention and treatment of diabetes with resveratrol in a non-obese mouse model of type 1 diabetes. Diabetologia 2011, 54, 1136-1146. [CrossRef] [PubMed]

(C) 2018 by the authors. Licensee MDPI, Basel, Switzerland. This article is an open access article distributed under the terms and conditions of the Creative Commons Attribution (CC BY) license (http:/ / creativecommons.org/licenses/by/4.0/). 